\title{
Genotoxicological Evaluation of NUTRALYS Pea Protein Isolate
}

\author{
Chentouf Aouatif, ${ }^{1}$ Ph. Looten, ${ }^{1}$ M. V. S. Parvathi, ${ }^{2}$ S. Raja Ganesh, ${ }^{2}$ and V. Paranthaman ${ }^{2}$ \\ ${ }^{1}$ Biology and Nutrition Department, Roquette Frères, 62136 Lestrem, France \\ ${ }^{2}$ International Institute of Biotechnology and Toxicology (IIBAT), Padappai, Tamil Nadu 601301, India
}

Correspondence should be addressed to M. V. S. Parvathi; parvathi@iibat.com

Received 21 December 2012; Accepted 27 January 2013

Academic Editors: S. T. Chu, A. Hakura, S. V. Kala, M. Valverde, S. M. Waliszewski, and K. Wohlfarth

Copyright (C) 2013 Chentouf Aouatif et al. This is an open access article distributed under the Creative Commons Attribution License, which permits unrestricted use, distribution, and reproduction in any medium, provided the original work is properly cited.

\begin{abstract}
NUTRALYS Pea Protein Isolate, a protein supplement, is a high-quality source of protein which is primarily emulsifying functional protein. We evaluated the genotoxic potential of NUTRALYS isolated from dry yellow pea, using three established genotoxicity tests (AMES test in vitro chromosomal aberration test, and in vivo micronucleus test) employing OECD guidelines under GLP conditions. In the bacterial reverse mutation test, NUTRALYS did not show positive responses in strains detecting point and frame shift mutations. In the chromosomal aberration test, NUTRALYS did not induce chromosome aberrations in the presence and absence of metabolic activation. In the bone marrow micronucleus test, NUTRALYS did not induce significant increases of micronucleated immature (polychromatic) erythrocytes in bone marrow of test animals.
\end{abstract}

\section{Introduction}

Human food contains essential nutrients that make up the source of metabolism and energy. For improvement of the health, additional ingredients are consumed in day-to-day life. For this purpose, many formulations are produced, and several natural sources are added to nutritional supplements in different forms to compensate the shortage of some nutrients. The use of nutritional supplements has remarkably increased in recent years [1].

NUTRALYS Pea Protein Isolate (Food grade supplement-by Roquette Frères) is a high-quality source of protein is extracted from the dry yellow pea which is primarily emulsifying functional protein. It is a vegetable protein rich in amino acids used in high protein foods and drinks. The pea is subjected to a wet process treatment. This process ensures that pea isolates with $85 \%$ to $90 \%$ protein are obtained, with a high level of functionality. It is a creamy colour powder, with protein content of $85 \%$.

To ensure the safe use and quality of dietary supplements, the FDA [2] recently announced regulations for good manufacturing practices for nutritional supplements. Recent studies projected plants to be important sources of biologically active products, many of which serve as models for the synthesis of a large number of medicines. Hence scientific studies have enabled use of plant products in the therapeutics of different diseases [3]. Usually consumers of food products do not find time or capacity to assess biochemical and safety data on every substance they consume or to assess for themselves on a daily basis the chemical components of every product they are supposed to be purchasing. In the case of food additives, Congress has entrusted the Food and Drug Administration (FDA) to direct the safety of food ingredients, including the premarket safety evaluation of new food additives intended for our foods. In this way consumers are unchained to make their own verdict on a product-byproduct basis for the food ingredient safety issues each time they make a purchase [4].

According to Food Safety Commission of Japan (FSCJ), 2010 [5], substances that are to be used as an alternative to ordinary food ingredients or for the purpose of nutritional enhancement or as a "food with nutritional claims" must be examined regarding their quality as a nutritional component as well as relatively to the intake levels of the same nutritional components that are available in other foods. It is preferable to examine as necessary in vitro studies and other studies conducted during pharmaceutical development or in other areas that are recommended for food additive studies. 
TABle 1: Positive mutagens for Salmonella typhimurium strains.

\begin{tabular}{lccccc}
\hline Method & Mutagen & No. of CAS & Solvent & $\begin{array}{c}\text { Conc. per } \\
\text { plate }(\mu \mathrm{g})\end{array}$ & $\begin{array}{c}\text { Responding Salmonella } \\
\text { strains }\end{array}$ \\
\hline \multirow{2}{*}{$\begin{array}{l}\text { Nonactivation (-S9) } \\
\text { (Direct acting mutagens) }\end{array}$} & Mitomycin C (Sigma, USA) & $50-07-7$ & Water & 0.5 & TA102 \\
& Sodium azide (Sigma, USA) & $26628-22-8$ & Water & 1 & TA1535, TA100 \\
& 9-Amitrofluorene (Sigma, USA) & $607-57-8$ & DMSO & 10 & TA98 \\
Activation (+S9) & Benzo(a)pyrene (Sigma, USA) & $50-32-8$ & DMSO & 10 & TA1537 \\
\hline
\end{tabular}

Genetic toxicity tests included in the standard combination are bacterial reverse mutation tests, chromosome aberration tests using cultured cells of mammals, and micronucleus tests on rodents. In all the three tests, NUTRALYS is considered to be nongenotoxic and safe to be used as dietary supplement.

\section{Material and Methods}

NUTRALYS Pea Protein Isolate (Food grade supplement-by Roquette Frères) is a high-quality source of protein extracted from the dry yellow pea which is primarily emulsifying functional protein. It contains $85 \%$ to $90 \%$ protein with a high level of functionality. It is a creamy colour powder, with protein content of $85 \%$.

Genetic toxicity tests included in the standard combination are bacterial reverse mutation tests, chromosome aberration tests using cultured cells of mammals, and micronucleus tests on rodents. All the tests were conducted at IIBAT, Padappai, India, a GLP compliant laboratory following suitable OECD guidelines after prior approval from Institutional Ethical Committee.

2.1. Ames Test. In order to assess the mutagenic potential study was performed with five tester strains of Salmonella typhimurium (TA100, TA102, TA1535, TA98, and TA1537, procured from Defence Research and Development Establishment (DRDE), Gwalior, India) tested in presence and in absence of metabolic activation. The assay was performed according to OECD Guideline 471, adopted July 21, 1997. The protein was dispersed in sterile millipore water, and the test solutions were thoroughly vortexed for homogeneity, before testing. In order to choose the range of doses for the test, the cytotoxic activity of the test item was determined. The cytotoxicity assay was carried out in strains TA98 and TA100 under the same conditions as the mutagenicity test with and without metabolic activation, using 2 plates per dose. Cytotoxicity was checked by microscopic examination of the background lawn. Seven test concentrations were prepared with $78.13,156.25,312.5,625,1250,2500$, and $5000 \mu \mathrm{g} / \mathrm{plate}$, separated by factor 2 spacing in the preincubation method in the presence and absence of S9. The plates were incubated for approximately $48-72$ hours at $37^{\circ} \mathrm{C}$, and the revertants were counted using digital colony counter (Scheutt Biotec De, UK). Five test concentrations of 312.5, 625, 1250, 2500, and $5000 \mu \mathrm{g} /$ plate with $10 \%$ S9 and without S9 along with solvent and positive controls (Table 1) were chosen for mutagenicity evaluation in the five tester strains.
2.2. In Vitro Chromosomal Aberration Test. Pea Protein was evaluated for its capacity to induce structural and numerical aberrations in cultured human peripheral blood lymphocytes. The study was conducted with the approval of Institutional Ethical Committee, IIBAT. The peripheral blood was obtained from three healthy adult ( $>30$ years age) nonsmoking male volunteers, without any recent history of illness, as is the guideline requirement. Informed consent was obtained from each donor. The assay was performed according to OECD Guideline 473, adopted July 21, 1997. The test substance was dispersed in sterile millipore water with a limit of solubility at $100 \mathrm{mg} / \mathrm{mL}$. A range finding study was performed both in the presence and absence of S9, to choose appropriate concentrations for the main study based on solubility, precipitation, and cytotoxicity based on Mitotic Index. Seven concentrations of 15.625, 31.25, 62.5, 125, 250, 500 , and $1000 \mu \mathrm{g} / \mathrm{mL}$ with concurrent solvent controls were set. Cells were treated with the test substance for 3 hours in the presence and absence of metabolic activation system (S9), and continuously for a 36-hour period in the absence of metabolic activation system (S9), and allowed for 33-hour expression in the case of 3-hour exposure. Single cultures were treated in the range finding study. Heparinized whole blood lymphocyte cultures were established in RPMI 1640 (GIBCO) medium along with other supplements. Cultures were incubated in PHA-M (GIBCO) containing medium for 48 hours, at $37 \pm 0.5^{\circ} \mathrm{C}$ in a humidified $5 \% \mathrm{CO}_{2}$ atmosphere. The cultures were treated with the test substance, solvent, and positive controls in the presence and absence of S9, at 48 hours from initiation of the cultures. Cultures were incubated in a humidified $5 \% \mathrm{CO}_{2}$ atmosphere at $37 \pm$ $0.5^{\circ} \mathrm{C}$ for 1.5 cell cycle times. One hour prior to harvest, $0.4 \mu \mathrm{g} / \mathrm{mL}$ of colchicine (Sigma, USA) was added to the cultures. The cells were pelleted, hypotonically shocked with freshly prepared and preincubated $0.075 \mathrm{M}$ potassium chloride (Merck) solution at $37 \pm 1^{\circ} \mathrm{C}$, and washed and fixed in 3:1 methanol and acetic acid. Slides were prepared from cells resuspended in fixative, by dropping technique, and were airdried. Metaphase preparations were stained with 3\% Giemsa (Merck). Two hundred well-spread metaphases were scored per concentration of test substance and solvent control, equally divided amongst the duplicates using trinocular microscope (Nikon, Japan).

2.3. In Vivo Micronucleus Assay. To detect genotoxic potential of Pea Protein Isolate in vivo, mouse micronucleus assay was performed by assessing the induction of micronuclei 


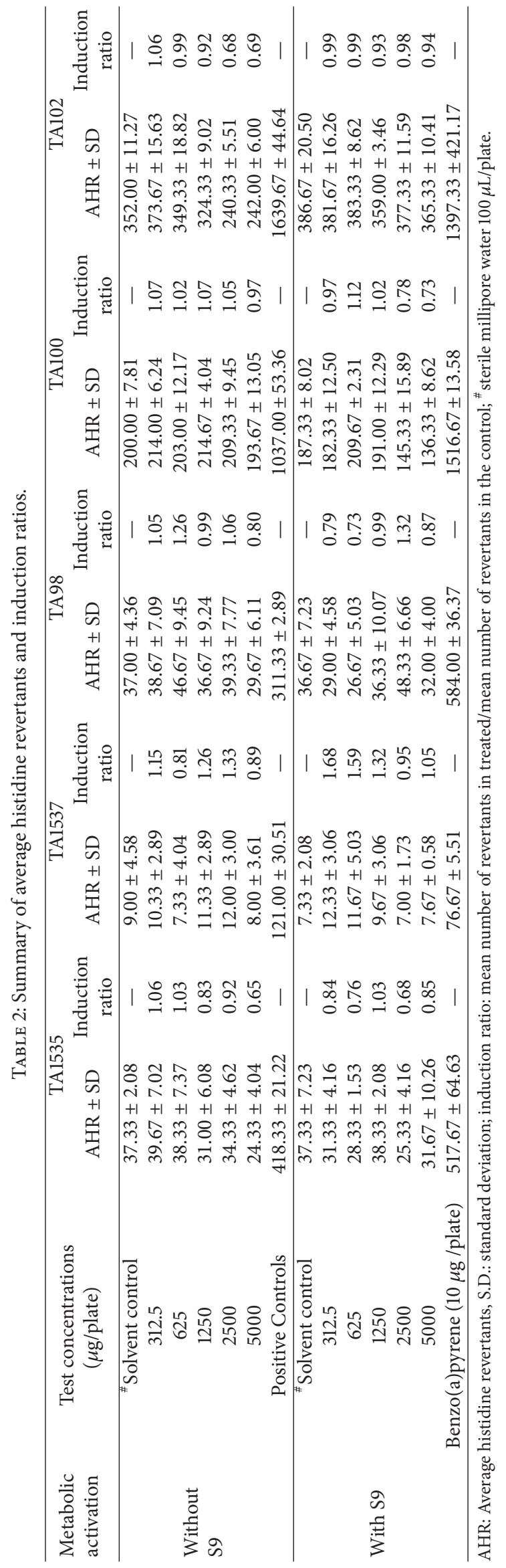


TABLE 3: Summary of in vitro chromosomal aberrations in human lymphocytes.

\begin{tabular}{|c|c|c|c|c|c|c|c|}
\hline \multirow{2}{*}{$\begin{array}{l}\text { Concentration } \\
(\mu \mathrm{g} / \mathrm{mL})\end{array}$} & \multirow{2}{*}{$\begin{array}{l}\text { Total no. of } \\
\text { metaphases } \\
\text { scored }\end{array}$} & \multicolumn{2}{|c|}{$3 \mathrm{~h}$ with S9 (10\%) } & \multicolumn{2}{|c|}{$3 \mathrm{~h}$ without S9 } & \multicolumn{2}{|c|}{ Continuous without S9 } \\
\hline & & $\begin{array}{l}\text { \% Numerical } \\
\text { aberrations }\end{array}$ & $\begin{array}{l}\text { \% Structural } \\
\text { aberrations } \\
\text { (exclusive to }_{\text {gaps) }}^{*}\end{array}$ & $\begin{array}{l}\text { \% Numerical } \\
\text { aberrations }\end{array}$ & $\begin{array}{c}\text { \% Structural } \\
\text { aberrations } \\
\text { (exclusive to }_{\text {gaps) }}^{*}\end{array}$ & $\begin{array}{l}\text { \% Numerical } \\
\text { aberrations }\end{array}$ & $\begin{array}{c}\text { \% Structural } \\
\text { aberrations } \\
\text { (exclusive to }^{\text {gaps) }}{ }^{*}\end{array}$ \\
\hline $\begin{array}{l}\text { Solvent control (sterile } \\
\text { millipore water } \\
50 \mu \mathrm{L} / 5 \mathrm{~mL} \text { culture) }\end{array}$ & 200 & 0 & 2.0 & 0 & 5.0 & 0 & 2.5 \\
\hline 125 & 200 & 0 & 1.5 & 0 & 2.5 & 0 & 2.5 \\
\hline 250 & 200 & 0 & 1.0 & 0 & 3.0 & 0 & 2.5 \\
\hline 500 & 200 & 0 & 2.5 & 0 & 5.0 & 0 & 2.5 \\
\hline Positive control ${ }^{\#}$ & 50 & 0 & 44.0 & 0 & 96.0 & 0 & 70.0 \\
\hline
\end{tabular}

${ }^{\#} 20 \mu \mathrm{g} / \mathrm{mL}$ cyclophosphamide (with S9); $0.8 \mu \mathrm{g} / \mathrm{mL}$ mitomycin C (without S9).

TABle 4: Percentage Mitotic Index.

\begin{tabular}{|c|c|c|c|c|c|c|}
\hline \multirow{3}{*}{ Concentration $^{*}(\mu \mathrm{g} / \mathrm{mL})$} & \multicolumn{6}{|c|}{ \% Mitotic index (MI) } \\
\hline & \multicolumn{2}{|c|}{ 3h with S9 (10\%) } & \multicolumn{2}{|c|}{ 3h without $\mathrm{S} 9$} & \multicolumn{2}{|c|}{ Continuous without S9 } \\
\hline & $\% \mathrm{MI}$ & $\begin{array}{c}\text { \% MI } \\
\text { inhibition** }\end{array}$ & $\% \mathrm{MI}$ & $\begin{array}{c}\% \mathrm{MI} \\
\text { inhibition }^{* *}\end{array}$ & $\% \mathrm{MI}$ & $\begin{array}{c}\text { \% MI } \\
\text { inhibition** }\end{array}$ \\
\hline $\begin{array}{l}\text { Solvent control } \\
\text { (sterile millipore water } \\
50 \mu \mathrm{L} / 5 \mathrm{~mL} \text { culture) }\end{array}$ & 3.0 & - & 2.35 & - & 3.1 & - \\
\hline $125^{@}$ & 2.65 & 11.66 & 2.4 & -2.13 & 2.95 & 4.84 \\
\hline $250^{@}$ & 2.9 & 3.33 & 2.95 & -25.53 & 3.55 & -14.52 \\
\hline $500^{@}$ & 2.8 & 6.67 & 2.85 & -21.28 & 2.85 & 8.06 \\
\hline Positive control $^{\#}$ & 2.6 & 13.33 & 1.7 & 27.66 & 1.65 & 46.77 \\
\hline
\end{tabular}

${ }^{*}$ Mean value of duplicate cultures.

${ }^{\#} 20 \mu \mathrm{g} / \mathrm{mL}$ cyclophosphamide (with S9); $0.8 \mu \mathrm{g} / \mathrm{mL}$ mitomycin C (without S9).

${ }^{@}$ Moderate sedimentation of test substance on slides.

${ }^{* *} \% \mathrm{MI}$ inhibition $=((\%$ mean MI of solvent control $-\%$ mean MI of test concentration $) /$ mean MI of solvent control $) \times 100$.

in polychromatic erythrocytes (PCEs) and determining the ratio of immature and mature erythrocytes in bone marrow cells, in compliance with the OECD guideline 474, 1997. The study was conducted with the approval of Institutional Animal Ethics Committee, IIBAT. Healthy male and female CD1 mice of 6-8 weeks of age were used for the study as per guideline's specification. Solubility of the test substance was achieved in millipore water (as complete dispersion). A range finding study was performed with doses of 320 , 800 , and $2000 \mathrm{mg} / \mathrm{kg}$ b.w. employing 2 mice/sex/dose with concurrent vehicle control. The mice were treated orally and administered a single treatment with $24 \mathrm{~h}$ sacrifice time point. A limit test was performed administering single- and twoday treatments ( $24 \mathrm{~h}$ apart) with the highest dose $2000 \mathrm{mg} / \mathrm{kg}$ b.w. Mice in the positive control group were given a single treatment of $40 \mathrm{mg} / \mathrm{kg}$ b.w. cyclophosphamide monohydrate (Sigma, USA), intraperitoneally. Mice were sacrificed at $24 \mathrm{~h}$ and $48 \mathrm{~h}$ following single treatment and in case of two-day treatment; mice in the vehicle control and high dose groups were sacrificed $24 \mathrm{~h}$ after the final administration of test substance. Mice in the positive control group were sacrificed at the end of $24 \mathrm{~h}$. Both femurs from each animal were rapidly dissected out and cleaned off the adherent tissue. The epiphyses were removed to obtain access to the bone marrow canal. Bone marrow cells were flushed out with $2.5 \mathrm{~mL}$ FBS (Biological Industries, European grade), and the recovered cells were centrifuged at $1600 \mathrm{rpm}$ for five minutes. The bulk of the supernatant fluid was discarded, and the cell pellet was resuspended in the remaining fluid with appropriate dilution. Smear was prepared by placing a single drop of the cell suspension on clean slides and then left to air-dry followed by ageing. Following fixation in methanol for ten minutes, slides were stained with $(1: 5)$ Giemsa solution (Merck) in water. A minimum of 2000 PCEs per mouse were scored in both sexes in each time point of sacrifice for the incidence of micronuclei. Cytotoxicity was assessed based on the ratio of immature (PCEs) and mature (NCEs) erythrocytes recorded from a total of 200 erythrocytes under trinocular microscope (Nikon, Japan).

\section{Results}

3.1. Ames Test. Cytotoxicity was not observed in terms of dose-dependent reduction in the number of revertant colonies and significant inhibition of background lawn, compared to the solvent control in the presence and absence of S9 in range finding study. Biological significance of the 
TABLE 5: Summary of micronucleus assay.

\begin{tabular}{|c|c|c|c|c|c|c|c|c|c|c|c|}
\hline \multirow{2}{*}{ Group/dose } & \multirow{2}{*}{$\begin{array}{c}\text { Treatment/sacrifice } \\
\text { Time point }\end{array}$} & \multicolumn{2}{|c|}{ Total PCE scored } & \multicolumn{2}{|c|}{ Total NCE scored } & \multicolumn{2}{|c|}{ PCE : NCE } & \multicolumn{2}{|c|}{ Total MN-PCE scored } & \multicolumn{2}{|c|}{$\% \mathrm{MN}-\mathrm{PCE}$ Mean $\pm \mathrm{SD}$} \\
\hline & & M & $\mathrm{F}$ & M & $\mathrm{F}$ & M & $\mathrm{F}$ & M & $\mathrm{F}$ & M & $\mathrm{F}$ \\
\hline G1 & Single $/ 24 \mathrm{~h}$ & 563 & 501 & 437 & 499 & 1.30 & 1.01 & 10 & 12 & $0.10 \pm 0.08$ & $0.12 \pm 0.08$ \\
\hline millipore & Single/48 h & 569 & 511 & 431 & 489 & 1.34 & 1.05 & 11 & 10 & $0.11 \pm 0.05$ & $0.10 \pm 0.04$ \\
\hline water & Two day/24 h* & 528 & 490 & 472 & 510 & 1.14 & 0.98 & 16 & 13 & $0.16 \pm 0.04$ & $0.13 \pm 0.08$ \\
\hline G2 & Single/24h & 541 & 539 & 459 & 461 & 1.18 & 1.18 & 10 & 12 & $0.10 \pm 0.05$ & $0.12 \pm 0.06$ \\
\hline $2000 \mathrm{mg} / \mathrm{kg}$ & Single/48 h & 563 & 555 & 437 & 445 & 1.31 & 1.26 & 15 & 14 & $0.15 \pm 0.08$ & $0.14 \pm 0.04$ \\
\hline b.w. & Two day/24 h* & 520 & 483 & 480 & 517 & 1.09 & 0.94 & 15 & 15 & $0.15 \pm 0.07$ & $0.15 \pm 0.04$ \\
\hline G3 & & & & & & & & & & & \\
\hline $\begin{array}{l}40 \mathrm{mg} / \mathrm{kg} \text { b.w. } \\
\text { CYP }\end{array}$ & Single/24 h & 506 & 528 & 494 & 472 & 1.04 & 1.13 & 92 & 80 & $0.92 \pm 0.18$ & $0.80 \pm 0.22$ \\
\hline
\end{tabular}

$24 \mathrm{~h}^{*}$ : Following last administration; M: male; F: female; CYP: cyclophosphamide (monohydrate); PCE: polychromatic erythrocyte; NCE: normochromatic erythrocyte; MN-PCE: micronucleated polychromatic erythrocyte.

results was considered first. There was no concentration related or reproducible increase in the number of revertant colonies in the employed test concentrations in any of the tester strains. No two- or threefold increases in the means of the revertant counts was observed in the test concentrations in all tester strains with and without S9. Positive controls exhibited a significant multifold increase in revertant counts $(P<0.05$, Dunnett's test). Thus, the negative result indicated that under these experimental conditions Pea Protein was nonmutagenic in the Ames Salmonella typhimurium reverse mutation assay (Table 2).

3.2. In Vitro Chromosomal Aberration Test. A moderate sedimentation of test substance was observed on slides in 125,250 , and $500 \mu \mathrm{g} / \mathrm{mL}$. Heavy compound sedimentation was observed at $1000 \mu \mathrm{g} / \mathrm{mL}$ on slides in range finding study. Considering the noncytotoxicity and sedimentation of test substance, doses 125,250 , and $500 \mu \mathrm{g} / \mathrm{mL}$ were chosen for the main study. In all the three treatment regimes (3-hour, $\pm S 9$ and continuous, - S9), treatment of cultures with Pea Protein Isolate resulted in an acceptable $(-25.53 \%$ to $11.66 \%) \% \mathrm{MI}$ inhibition (Table 4). The percentage aberrations of all PeaProtein-Isolate-treated cultures were not significantly different from the concurrent solvent control cultures in consensus with the scientific judgement (Table 3). Positive controls exhibited a significant increase in the percentage aberrations $(P<0.05$, Dunnett's test). It is therefore concluded that, under the conditions of the test, Pea Protein Isolate did not induce genotoxic response in human lymphocytes when tested up to concentrations inducing acceptable levels of cytotoxicity:

$\%$ Structural aberrations

$$
\begin{aligned}
= & \frac{\text { Total aberrations from duplicate cultures (excluding gaps) }}{\text { Total no. of metaphases scored }} \\
& \times 100 \text {. }
\end{aligned}
$$

3.3. In Vivo Micronucleus Assay. No mortality was observed in any of the groups. In the preliminary test there was a mild dose-dependent increase in the PCE: NCE ratio observed in females (PCE: NCE ratio of $>1$ ) without disturbance in cellularity, and a ratio of $>1$ was observed in males at $800 \mathrm{mg} / \mathrm{kg}$ b.w., exhibiting a similar trend to that of the concurrent vehicle control. In the limit test no evident increase in the frequencies of MN-PCE was observed in the dose group compared to that of the concurrent vehicle control groups in all time points of sacrifice (Table 5). However, an evident increase in the MN-PCE ( $>2$ fold) was observed in the positive control group over the vehicle control and dose groups, thus validating the sensitivity of the assay $(P<0.05$, Dunnett's test). From the previous results, giving credence to the scientific judgement, it was concluded that Pea Protein Isolate was nongenotoxic in single- and two-day treatments under the test conditions employed.

\section{Discussion}

In this paper, the possible toxic effects of the Pea Protein Isolate NUTRALYS were evaluated in first-barrier trials. Unifying all the information, the data suggest that the Pea Protein does not induce toxic effects, which could represent the safe implementation for nutritional supplementation of this product. Many nutritional supplement ingredients like Avemar pulvis, comprising fermented wheat germ, were tested for safety evaluation by acute, subacute, subchronic, and genetic toxicity studies and found to have no adverse effects at exposures far in excess of those that are expected to result from their intended use [6]. In its 2004-2009 Strategic Plan NIH's Office of Dietary Supplements looks for research assessing the effects of dietary supplements on biomarkers associated with chronic diseases, optimal health, and improved performance [7]. For this purpose genotoxic evaluation has been carried out to propose the genotoxic risk to the end user. The strategic recommendation of short-term genotoxic tests to assess the toxicity of the food ingredients [8] follows Ames bacterial reverse mutation test an in vitro chromosomal aberration test followed by an in vivo micronucleus test. This strategy has been implemented and the safety data was proposed for this food supplement. All three tests in the battery elucidated the non genotoxic nature of NUTRALYS Pea Protein Isolate and hence are recommended to be used as a dietary supplement for human, for which the humans equivalent dose was extrapolated from 
mice oral dose used in the micronucleus assay using the calculation from FDA guidance document-"Estimating the Maximum Safe Starting Dose in Initial Clinical Trials for Therapeutics in Adult Healthy Volunteers."

Human equivalent dose in $\mathrm{mg} / \mathrm{kg}$ b.w. $=$ Mice dose in $\mathrm{mg} / \mathrm{kg}$ b.w. $/ 12.3=2000 \mathrm{mg} / \mathrm{kg}$ b.w. $/ 12.3=162.6 \mathrm{mg} / \mathrm{kg}$ b.w.

\section{Conclusion}

Finally NUTRALYS Pea Protein Isolate is considered nonmutagenic and nongenotoxic at the conditions employed in Ames test, in vitro chromosomal aberration test, and in vivo micronucleus test and suits a toxicologically safe protein supplement.

\section{References}

[1] C. Noonan and W. P. Noonan, "Marketing dietary supplements in the United States: a review of the requirements for new dietary ingredients," Toxicology, vol. 221, no. 1, pp. 4-8, 2006.

[2] United States Food and Drug Administration, "Final Rule for Current Good Manufacturing Practices (CGMPs) for Dietary Supplements," 2007, http://edocket.access.gpo.gov/2007/073039.htm/.

[3] L. B. Lima, C. F. Vasconcelos, H. M. Maranhão et al., "Acute and subacute toxicity of Schinus terebinthifolius bark extract," Journal of Ethnopharmacology, vol. 126, no. 3, pp. 468-473, 2009.

[4] A. M. Rulis and J. A. Levitt, "FDA'S food ingredient approval process: safety assurance based on scientific assessment," Regulatory Toxicology and Pharmacology, vol. 53, no. 1, pp. 20-31, 2009.

[5] Food Safety Commission of Japan (FSCJ), "Policies for assessments of the effect of food on health regarding food additives," Guideline for Assessment of the Effect of Food on Human Health Regarding Food Additives, article 4, 2010.

[6] J. T. Heimbach, G. Sebestyen, G. Semjen, and E. Kennepohl, "Safety studies regarding a standardized extract of fermented wheat germ," International Journal of Toxicology, vol. 26, no. 3, pp. 253-259, 2007.

[7] The Office of Dietary Supplements, "Office of the Director National Institutes of Health: Promoting Quality Science in Dietary Supplement Research, Education, and Communication: A Strategic Plan for the Office of Dietary Supplements," 2004, http://ods.od.nih.gov/pubs/SP10B.web.pdf.

[8] Redbook 2000, "IV. A Introduction: Guidelines for Toxicity Studies," IV.C. 1. Short-Term Tests for Genetic Toxicity, July 2000. 

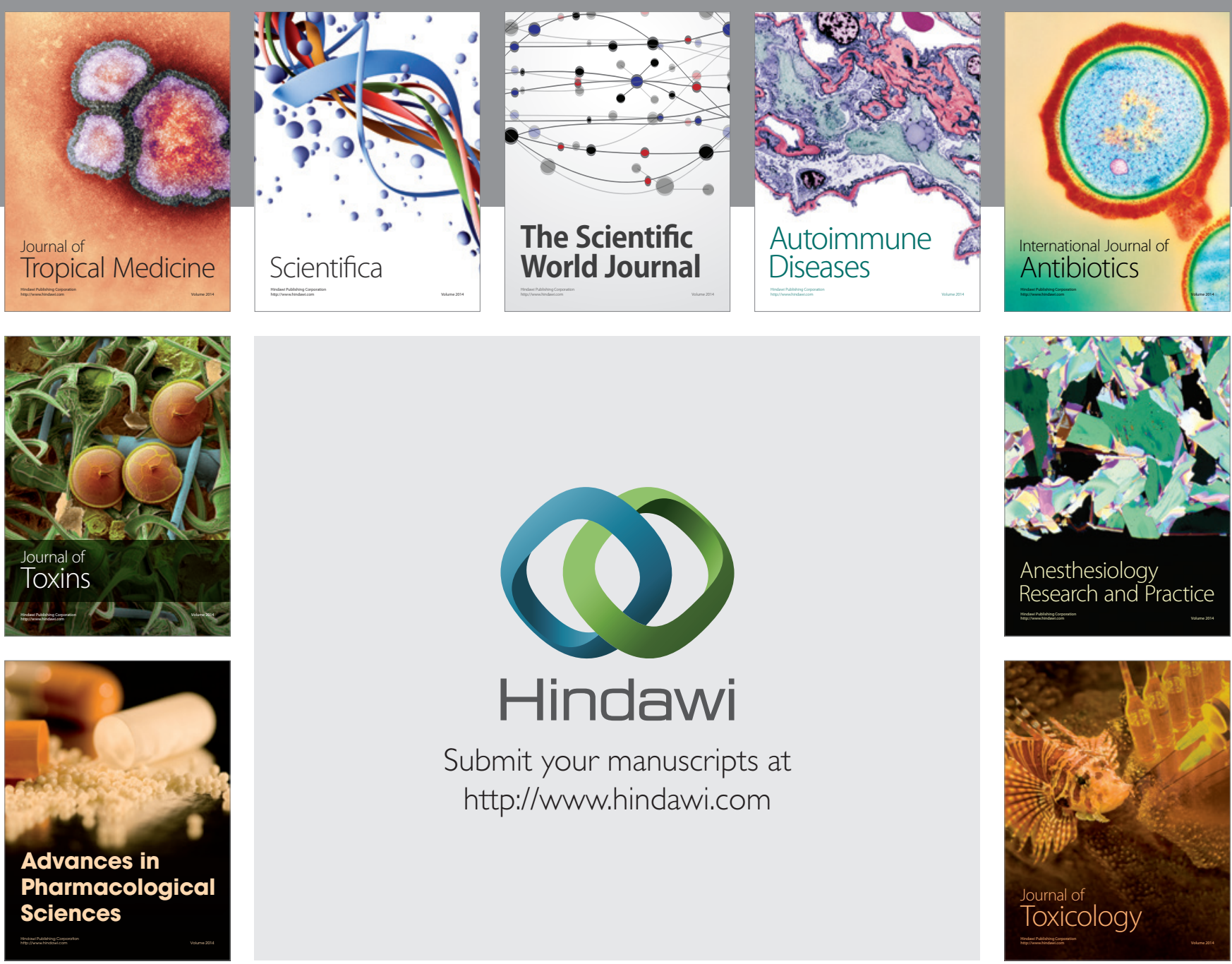

\section{Hindawi}

Submit your manuscripts at

http://www.hindawi.com
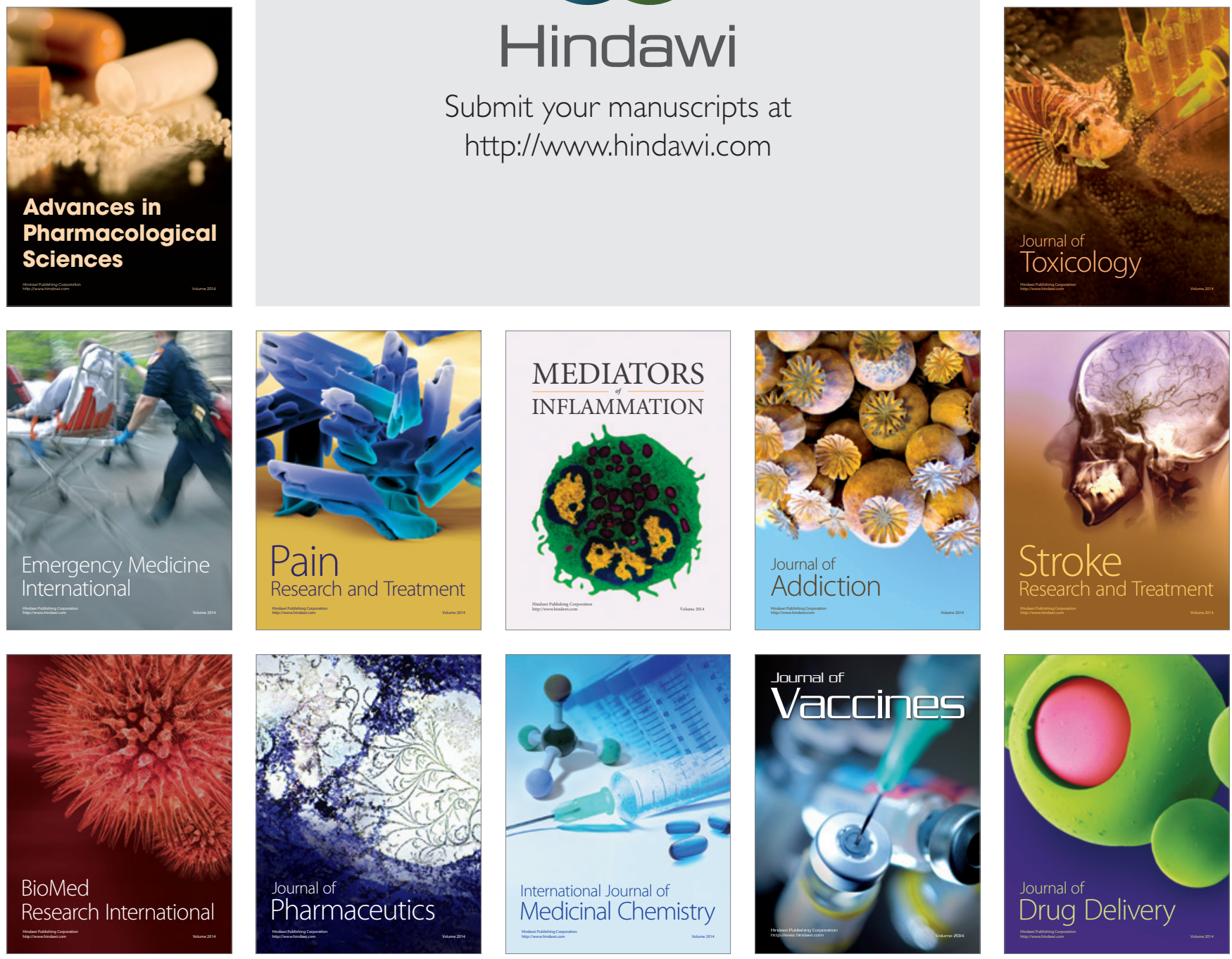